\title{
Calcium Carbonate and Derived Products
}

\author{
N. K. Mathur ${ }^{1}$, S. R. Jakhar ${ }^{2}$, Rajendra Mathur ${ }^{3}$ \\ Department of Chemistry, Jai Narain Vyas University, Jodhpur -342005 (India) \\ ${ }^{1}$ Retd. Professor \& Head, Department of Chemistry, Jai Narain Vyas University, Jodhpur -342005(India) \\ ${ }^{2}$ Department of Geology, Jai Narain Vyas University, Jodhpur -342005 (India)
}

\begin{abstract}
Calcium carbonate is one of the most versatile and widely distributed mineral. Various forms of this mineral with variety of chemical composition, though differing to only minute level, make it highly attractive for various applications. These minerals not only differ in chemical composition but also physical forms; such as amorphous, calcite etc. This article deals with a comprehensive but brief over view of calcium carbonate and its applications.
\end{abstract}

Keywords: Calcium carbonate, lime stone

\section{Introduction}

Calcium carbonate, or $\mathrm{CaCO}_{3}$, comprises more than $4 \%$ of the earth's crust and is found throughout the world. It's most common natural forms are chalk, limestone, and marble, produced by the sedimentation of the shells of small fossilized snails, shellfish, and coral over millions of years. Although all three forms are identical in chemical terms, they differ in many other respects, including purity, whiteness, thickness and homogeneity. Calcium carbonate is one of the most useful and versatile materials known to man. Calcium carbonate $\left(\mathrm{CaCO}_{3}\right)$, in the form of chalk, limestone (figure 1A, 1B \& 3), marble (figure $2 \& 5$ )and calcite (figure 4 ) is one of the most widespread mineral of the earth.Chalkis a fine, microcrystalline material, which has been used as a tool for writing, for last thousands of years. As a school boy, one might haveencountered calcium carbonate basedblackboard chalk-sticks.Term chalk has been used for the friable limestone which is composed of microscopic remains of marine organisms and on crushing gives fine powder. It is also used in the manufacture of paint, distemper, filler in rubber goods, etc. Normal soil, besides silica and silicates, is rich in carbonate-minerals ( 4\%); particularly those of calcium and magnesium. Natural water (ground, rivers and lakes, and sea) contains varying amount of calcium carbonate, which is reversibly solubilised (Eq.-1) as bicarbonate on absorbing atmospheric carbon dioxide and which causes water hardness

$$
\mathrm{CaCO}_{3}+\mathrm{H}_{2} \mathrm{O}+\mathrm{CO}_{2}=\mathrm{Ca}\left(\mathrm{HCO}_{3}\right)_{2}(\mathrm{Eq} .-1)
$$

Even the pearls, which are produced in certain shelled seaanimals, are mainly composed of calcium carbonate. These are highly valued due to their limited natural occurrence. Pearls are used as gems in ornaments. Cultured pearls are now produced by harvested shelled animals.

Crystalline calcium carbonate; calcite is also known as 'calcspar. The calcite crystal generally is considered a rhombohedron because of its cleavage properties. Cleavage is what causes crystals to angle where the bonding forces are weak and are apt to break into planes. Calcite is unique in that its cleavage takes three distinct directions. Specific gravity range is $2.71-2.72$. Melting point is about $825^{\circ} \mathrm{C}$. It decomposes, giving off $\mathrm{CO}_{2}$ leaving $\mathrm{CaO}$ (or lime), which melts at about $2570^{\circ} \mathrm{C}$. Colourless white but also various shades like pink, brown etc. depending upon the impurities present. Fracture varies, depends upon structure. Its different varieties are, transparent to opaque. It is brittle. There are more than 300 forms of calcite crystals. Another important property of the calcite crystal is its property of double refraction. Double refraction occurs when a ray of light travels through a medium and is split into two different beams, one traveling slowly, one traveling fast. The two different beams are bent at two different angles of refraction. As a result of this property a person looking through calcite sees two images. This property of double refraction is a feature valuable to a number of optical applications. Calcite is often very pure however; sometimes part of the calcium is replaced by magnesium, iron or manganese. It is often mixed with impurities, such as silica, clay, organic matter, limestone or hematite.Calcite occur in a great variety of forms, the more important of which are as follows;dogtooth spar, which occurs in acute, scalenohedral crystals; nailhead spar, which occurs in flat rhomohedral crystals, satin spar (term also used for a variety of gypsum), which is fibrous and has a silky luster, iceland spar or ordinary calcite deposited from solution as vein fillings etc. The only form of calcite or crystallized calcium carbonate which has properties and uses distinct from other forms and for which there are no entirely satisfactory substitutes in the finest of optical instruments is Iceland Spar. Transparent calcite was discovered in Iceland and become widely known, hence the name 'Iceland Spar'. Iceland spar is the name given to a pure crystallized form of calcite which is highly transparent and free from defects to be used in the manufacture of optical instruments. The properties in Iceland spar of value are transparency, double refraction or very high birefringence and ability to polarize light. Aragonite has the same chemical composition as calcite, but it crystallizes in the orthorhombic system, often in radial, columnar, or fibrous aggregates. It has a hardness of 3.5 to 4, specific gravity 2.9 to 3 ; imperfect prismatic cleavage; and conchoidal fracture. Commercially, it has no distinctuses. It is however, an unstable mineral, found mainly associated with gypsum beds and the tests of reef building corals. The Nicol prism which finds applications in the microscope and polariscope is the most common use. It is used in eyeglasses and for windows in trains, planes, and autos to remove a 


\section{International Journal of Science and Research (IJSR) \\ ISSN (Online): 2319-7064 \\ Index Copernicus Value (2013): 6.14 | Impact Factor (2015): 6.391}

portion of light, thereby eliminating glare. In its pulverized form, calcite is used in many industries as filler chiefly in textile, rubber and paint and distemper industries and as a carrier in insecticide preparations. The glass and ceramic industries are the principal consumers. In ceramic industries, it forms an important constituent of certain glazes and enamels. Other uses of calcite are in the manufacture of cement, bleaching powder, calcium, carbide, metal polish and as a fluxing agent in the manufacture of electrodes.

Marble is basically a carbonate rock, which geologically gets deposited as chemogenic sediments in the sea and subsequently, became marble by recrystallization during metamorphism. The parent rock of marble is limestone. It iscapable of taking a high polish, formed due to crystallization of calcium carbonate underhigh temperature and pressure over millions of years. Marble is believed to be resulted from regional or rarely contact metamorphism of sedimentary carbonate rocks, either limestone or dolostone or metamorphism of older marble. This metamorphic process causes a complete recrystallization of the original rock into an interlocking mosaic of calcite, aragonite and/or dolomite crystals.Commercially, the term marble is extended to include any rock composed of calcium carbonate that takes a polish, available in blockable sizes and also includes some ordinary limestone.

Large deposits of marble are found in North America, many countries inEurope and in India (Makarana townand various locations near Udaipur city, in Rajasthan). Italy is the home of the pure white 'statuaries', a form of marble, from which Michelangelo and many other sculptures's created their master pieces (Figure-5).Pure white marble is the result of metamorphism of very pure limestones. The characteristic swirls and veins of many coloured marble varieties are usually due to various mineral impurities such as clay, silt, sand, iron oxides, or chert which were originally present as grains or layers in the limestone. These various impurities have been mobilized and recrystallized by the intense pressure and heat of the metamorphism.

Though, the different forms of calcium minerals have nearly the same chemical composition, yet they differ in many respects, e.g. their purity, whiteness, thickness of a deposit and its homogeneity. Calcium carbonate is one of the most useful and versatile materials known to man and used for thousands of years.

Biogenic Source: Calcium carbonate is a biogenic material. Richer deposits of calcium carbonatewere produced by the sedimentation of the shells ofsnails, shellfish, and corals, which gotfossilized over millions of years.Richer deposits of calcium carbonate in different continents of the world are nearly of the same geological age. Hence, it has been suggested that these deposits of calcium carbonate (chalk, and marble) were formed in those parts of earth, which for millions of years, remained covered with shallow water and where shelled organism thrived. For these organism to grow there was a need for a protective shell and skeleton of calcium carbonate. Even today the egg-shell of birds and all other egg laying animals are composed of $>95 \%$ calcium carbonate.
Formation of these deposits has been offered as a proof of torrential rains and flooding, described in Hindu-Mythology (Flooding or the Mahapralaya,ofMaharishi Manu's period). In Jew, Buddhist, Christian and Muslim religious books it has been described as Biblical-Floodsand survival of Adam and Eve along with most of the animals, using a boat.

Applications: Calcium carbonate has been used from as early as 40,000 BC to present day. The history of calcium carbonate illustrates how we have been able to utilise the unique properties of this mineral in applications ranging from prehistoric cave paintings to modern paper and plastic manufacturing.Limestone, either as such or after calcination to lime, has many uses in chemical industry, such as in the manufacture of lime, Portland cement, alkali, glass, paper, calcium carbide, in sugar refining, as a flux in iron \& steel smelting, and as fillers for many purposes, agriculture, building construction, road stone, railroad ballast, in soil stabilization etc. and it will only be possible here to outline the specification requirements of a few of the more important uses.

\section{Marble as a Building Material}

As marble, calcium carbonate has been extensively used in building industry. Old temples and monuments, king's palaces, grave-stones, flooring-tiles etc. are made from marble. TajMahal, the tomb of mogul king Shahjahan's queen Mumtaj and many temples in India are exclusively built of marble. Marble-tiles are extensively used in flooring and for making grave-stones. Marble statues, including those of Hindu-gods and art-pieces have been made for centuries.

\section{Limestone, Lime and Cement}

Low grade calcium carbonate (limestone $~ 70 \%$ ) on burning in lime-kilns produces 'hydraulic-lime' (an engineering term, used for materials having property of setting into a hard mass). This has conventionally been used in building constructionwork. Impurities (oxides of aluminum, iron and silica), present in hydraulic lime, makes it a very suitable binder for bricks and stones in construction work. All around the world, using lime-mortar, human skill and labor, all the prehistoric structures, which we know even today, were built. These include, from a common-man's habitat, to the king's palaces and forts, temples (including those in Egypt, Greece and in Rome).

Before the technology of making cement was developed, hydraulic lime, mixed with sand (silica), was the exclusive building material in the form of 'lime-mortar', used for construction work, all over the world. At Portland Town in UK, the naturally occurring limestone had all the components of cement. This on proper burning produced cement like material. Hence the name 'Portland-Cement' was introduced.

Cement industry is probably the largest consumer of limestone. Almost 1.5 tone of limestone is required for each tone of cement produced. The manufacture of Portland cement is carried out by calcining a carefully proportioned mixture of calcium carbonate and silicates of aluminium. Limestone containing about $45 \% \mathrm{CaO}$ and above is usually preferred for the manufacture of cement. Magnesia content 


\section{International Journal of Science and Research (IJSR) \\ ISSN (Online): 2319-7064 \\ Index Copernicus Value (2013): 6.14 | Impact Factor (2015): 6.391}

in the stone should ideally be less than $3 \%$, although as high as $5 \% \mathrm{MgO}$ is used by the industry. The proportion of $\mathrm{Al}_{2}$ $\mathrm{O}_{3}+\mathrm{Fe}_{2} \mathrm{O}_{3}: \mathrm{SiO}_{2}$ should be 1: 2.5. Magnesia, sulphur and phosphorus are regarded as most undesirable impurities. The presence of phosphorus and $\mathrm{P}_{2} \mathrm{O}_{5}$ more than $1 \%$ slows down the setting time of Portland cement. The cement industry in India in general prescribes the following specifications of limestone:-

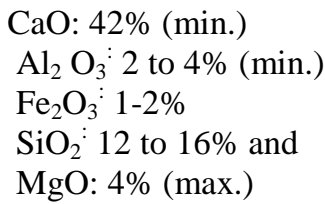

Hydraulic limes provide a useful building material where a product of less strength than Portland cement, but more easily manufactured, can be used.

\section{Limestone and Cement Industry in Western India}

Besides Himachal-Pradesh, Rajasthan and Gujarat (the north and western region of India), have large deposits of limestone. This has resulted in development of lime and cement industry in these regions. In Rajasthan, besides cement grade ( $70 \%$ ), lime-stone ofhigh purity ( $>90 \%$ ) occurs in Sojat and Gottan towns, which on burning produce 'fat-lime' (engineering term for quick lime, or $\mathrm{CaO}$ of purity 95\%). Fat-lime is not very suitable for building construction. On hydration into $\mathrm{Ca}(\mathrm{OH})_{2}$, it is used for white-washing of buildings, water and sewage treatment and also used for several industrial purposes, e.g. in manufacture of soda-ash and 'precipitated calcium-carbonate'.

Paper, Plastics, Paints, and Coatings: Calcium carbonate is the most widely used mineral in the paper, plastics, paints and coatings industries both as a filler - and due to its special white color - as a coating pigment. In the paper industry it is valued worldwide for its high brightness and light scattering characteristics, and is used as an inexpensive filler to make bright opaque paper. Filler is used at the wetend of paper making machines, and calcium carbonate filler allows for the paper to be bright and smooth. As an extender, calcium carbonate can represent as much as $30 \%$ by weight in paints. Calcium carbonate also is used widely as filler in adhesives, and sealants.

Personal Health and Food Production: Calcium carbonate is used widely as an effective dietary calcium supplement, antacid, phosphate binder, or base material for medicinal tablets. It also is found on many groceries store shelves in products such as baking powder, toothpaste, dry-mix dessert mixes, dough, and wine. Calcium carbonate is the active ingredient in agricultural lime, and is used in animal feed. Calcium carbonate also benefits the environment through water and waste treatment.

\section{Natural and cultured Pearls}

Pearl is a spherical object, produced within the soft mantle tissues of living shelled mollusk. It is mainly composed of concentric layers of crystalline calcium carbonate. An ideal pearl should be perfectly round and smooth. Many other shapes of pearls e.g. baroque pearls also occur. The finest quality of natural pearls, are regarded as valued gemstone beauties for centuries. Pearls have become metaphor as valuable (even more than gold) and so admirable that these were preferred by the old kings and nobles. The most valuable pearls occur spontaneously in the wild, but these are extremely rare. These wild pearls are referred to as natural pearls.

Culturedpearls are harvested from freshwater pearl-oyster/ freshwater mussels. These make up the majority of the pearls currently marketed. Pearls are sometimes crushed and used in cosmetics, medicines and paint formulations.

Uniqueness of pearls is due to their luster, arising due to the reflection, refraction and diffraction of light from its numerous, thin, translucent layers. Successive and overlapping layers of calcium carbonate, breakup and produce luster (iridescence) in a pearl. Cultured, freshwaterpearls can be dyed into yellow, blue, green, pink and black colors, and yet have a metallic luster. Being primarily made of calcium carbonate, pearls dissolves even in weak acids (vinegar or acetic acid) to liberate carbon dioxide, with formation of calcium acetate (Eq.-2).

$\mathrm{CaCO}_{3}+2 \mathrm{CH}_{3} \mathrm{COOH} \rightarrow \mathrm{CO}_{2}+\left(\mathrm{CH}_{3} \mathrm{COO}\right)_{2} \mathrm{Ca}+\mathrm{H}_{2} \mathrm{O}$ (Eq.-2)

\section{Precipitated Calcium Carbonate: An Industrial Raw-Material}

Somewhat less pure calcium carbonate (powder form)is produced during processing (cutting and polishing) of marble. Even then, it has a good commercial value. Suchbyproduct type of industrial material is called 'Ground Calcium Carbonate' (GCC).GCC, as the name implies, involves crushing and processing of limestone-waste to create a powder form. It is then graded by its particle-size and other properties, (e.g. purity and whiteness), for certain industrial applications. In the form of pharmaceutical tablets, it is given as a calcium supplement. It is also added in cowfeed and feed for egg producing birds, e.g. hen.

Highly pure calcium carbonate is prepared by passing carbon dioxide gas into a solution/ suspension of calcium hydroxide. In chemistry labs, a test for carbon dioxide is performed by passing the gas into lime-water, which turns milky due to formation of suspended calcium carbonate. Lime-water contains a very low concentration of calcium hydroxide and with excess carbon dioxide it again becomes clear due to the formation of soluble bicarbonate, $\mathrm{Ca}\left(\mathrm{HCO}_{3}\right)_{2}$.

Calcium carbonate formed, by precipitation ishighly pure, and the product is called 'Precipitated Calcium Carbonate' or (PCC). PCC has a very fine and controlled particle size, of the order of 2 microns.

\section{Manufacturing "Precipitated Calcium- Carbonate"}

Main features associated with the process for manufacturing 'Precipitated Calcium-Carbonate', basically comprises of: 1) Raw-materialmust be a high-purity limestone (>95\%) 


\section{International Journal of Science and Research (IJSR) \\ ISSN (Online): 2319-7064 \\ Index Copernicus Value (2013): 6.14 | Impact Factor (2015): 6.391}

2) Vertical Lime kiln for burning limestone to produce quick-lime(Carbon dioxide gas produced due to decomposition of lime-stone and burning of fuel is circulated after thorough washing into slaked lime; as detailed under clause- 5 below).

3) The fuel used must be a low ash coal or a liquid (Petroleum-based).

4) On burning quick-lime (in the form of lumps) are produced, which are separated from ash and low-grade powder.

5) Lumps are slaked (water is kept in a large circular-tank), provided with stirring arrangement. This produces limeslurry or slaked-lime.

6) Carbon dioxide gas is passed into the tank of slaked-lime to form calcium carbonate.

7) Since calcium carbonate has only limited water solubility it is precipitated out.

8) Precipitated (low-density and fluffy) calcium carbonate thus produced is filtered, dried and packed. To make the product compatible to commonly used rubber, plastics and paints it is made hydrophobic. Thus, it is often, precoated with mineral-oil, suitable coupling agents based on titanium, zirconium, aluminium etc.

9) Uses- Bulking-agent, binding agent and as a source of calcium, in medicine-tablets, paints-additive, talcumpowders, additive for plastics.

\section{Reactions}

\author{
In kiln $\mathrm{CaCO}_{3} \rightarrow \mathrm{CaO}+\mathrm{CO}_{2}$ \\ Formation of slaked lime $\mathrm{CaO}+\mathrm{H}_{2} \mathrm{O} \rightarrow \mathrm{Ca}(\mathrm{OH})_{2}$ \\ Carbonization $\mathrm{Ca}(\mathrm{OH})_{2}+\mathrm{CO}_{2} \rightarrow \mathrm{CaCO}_{3}$
}

PCC is also known as its 'calcite'and'aragonite' phases. Sometimes, it can be a mixture of these two. Its particle size varies from less than a micron to several microns in diameter. It is used as filler in rubber and plastics and forms a constituent of paints, printing-inks. It is used in paper coatings. Crystals of commercial PCC can have different shapes. For calcite phase, it hasrhombic-conical or spherical shapes, while in aragonite phase it forms irregular polygon and needle shaped crystal.

The basic principle involved in making of precipitated calcium carbonate involves a slow generation of carbonate ions in a suspension of calcium hydroxide at a temperature above a given minimum value, to maintainsuper-saturation of calcium carbonate below a given maximum value.

\section{Mineral Treatment Processes}

Considerable quantities of high calcium lime, either in the form of quicklime, hydrated lime or milk lime are used in floatation processes for the separation and concentration of minerals.

\section{Metallurgical uses}

Both limestone and lime are used in very considerable quantities as fluxing. Calcium carbonate is the most common flux used in various metallurgy operations. It is used in iron \& steel, Ferro-alloys, foundry plants and secondary steel manufactures. It is also used in smelting of copper and lead as fluxing agent.

Limestone is used in iron \& steel industry, both in the blast furnace and steel melting shop (S.M.S.). It has two basic functions, first to lower the temperature of melting and second to form calcium silicate by combining with silica of the iron ore which comes out as slag. For steel melting shop purpose good fluxing limestone low in acid constituents such as silica, alumina, sulphur and phosphorus is required. The limestone should be dense, massive, preferably fine grained, compact and non-fritting on burning.

\section{Alkali and allied chemicals}

Large quantities of high calcium limestone are used in the manufacture of Soda ash by the ammonia-soda process, as each ton of soda ash made requires about 1-1.25 tons of limestone. Preference is usually shown for stone in lumps between 1 and 4 inch in diameter. Desirable specifications for soda-ash limestone are:

$$
\mathrm{CaCO}_{3}: 90-99 \%
$$

$\mathrm{MgCO}_{3}: 0.6 \%$

$\mathrm{Fe}_{2} \mathrm{O}+\mathrm{Al}_{2} \mathrm{O}_{3}+\mathrm{SiO}_{2}: 0.3 \%$

In the manufacture of caustic soda from soda ash, lime is used either in the form of quick lime or hydrated lime. In manufacturing of bleaching powder, ceramic uses, textile industry, leather dressing, varnish manufacture, Calcium Carbide, Carbon Dioxide, Sodium bicarbonate and calcium chloride. Precipitated calcium carbonate is used for cosmetics.

\begin{abstract}
Abrasives: Certain dolomitic limestones, on suitable calcination so as to avoid overburing, yield a lime which is utilized as a mild abrasive for polishing silver plate, copper, brass, nickel and other metallic surface.
\end{abstract}

Agricultural Uses: Large quantities of ground limestone, quick and hydrated lime are used in agriculture principally to ameliorator soil conditions. The functions of lime in this connection including the improvement of the texture of clay soils by flocculating colloidal matter and so making heavy soil more granular, converting insoluble potash minerals to a form in which the potash is available for plant nutrition, providing a suitable environment in which soil bacteria can convert vegetable matter into humus and reducing the acidity of peaty soils.

Ground limestone is often used as filler in compound fertilizer both to add to the weight and to prevent caking. But in the manufacture of calcium ammonium nitrate fertilizer, limestone is used only as carrier. Limestone is also used for silica brick and grease manufacture

Stabilization of soils: Increasing use is being made of hydrated lime for the stabilization of road surfaces. When lime is added in small quantities to plastic, fine grained clay soils, or to coarse grained (gravely) soils containing high plastic binder, it decreases the plasticity of the soil and increases its compressive strength.

Rock or mineral wool: Considerable quantities of impure limestone are used, in the manufacture of rock wool which is 


\section{International Journal of Science and Research (IJSR) \\ ISSN (Online): 2319-7064 \\ Index Copernicus Value (2013): 6.14 | Impact Factor (2015): 6.391}

useful heat insulating material and also used in glass manufacture.

Mine Dusting: Various types of finely ground mineral products, including limestone, are spread in dry bituminous

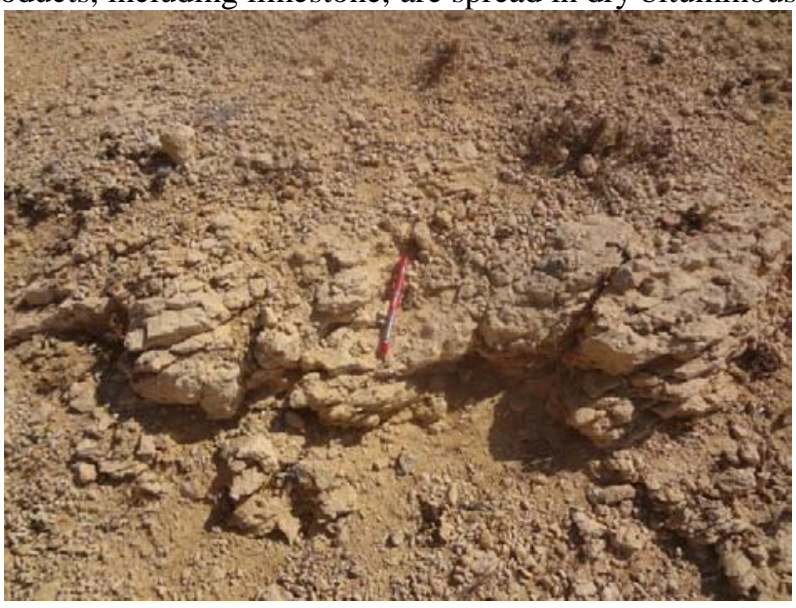

Figure 1(A): A photograph of fossiliferous limestone used for cement manufacturing in Kachchh, Gujarat

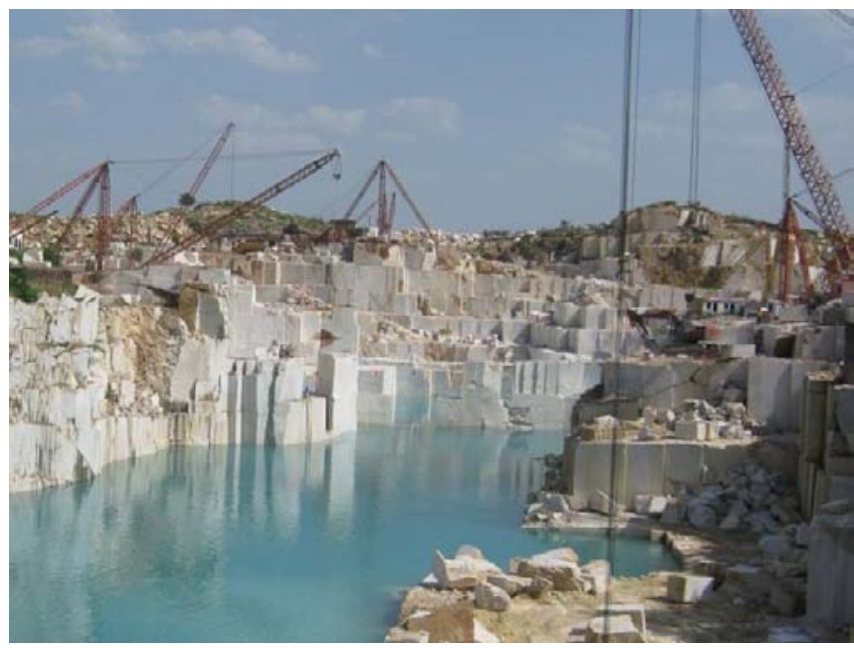

Figure 2: A view of Marble Mine of Tripurasundri, Banswara, Rajasthan

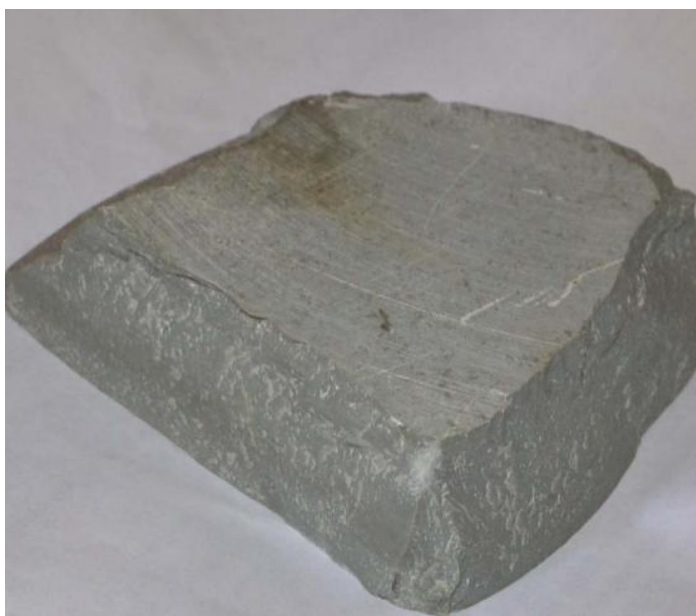

Figure 1 (B): Limestone, a calcium carbonate bearing sedimentary rock. coal mines in order to lessen the spreading of fine particles of coal in the air and so to reduce the risk of explosions.

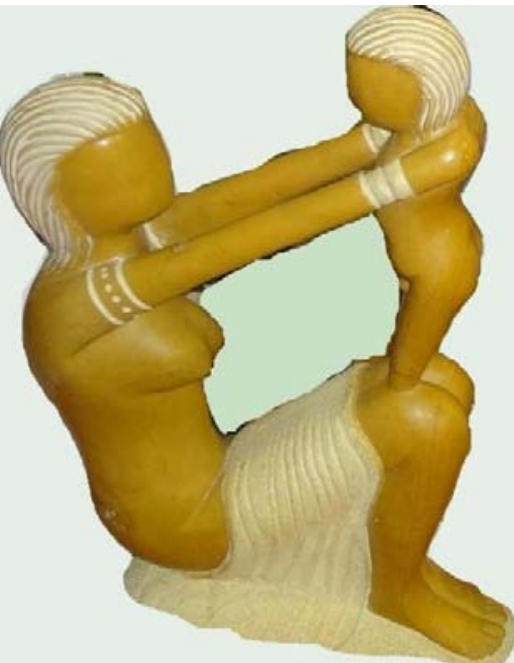

Figure 3: A finished statue carved out of Jurassic age Yellow Limestone of Jaisalmer.

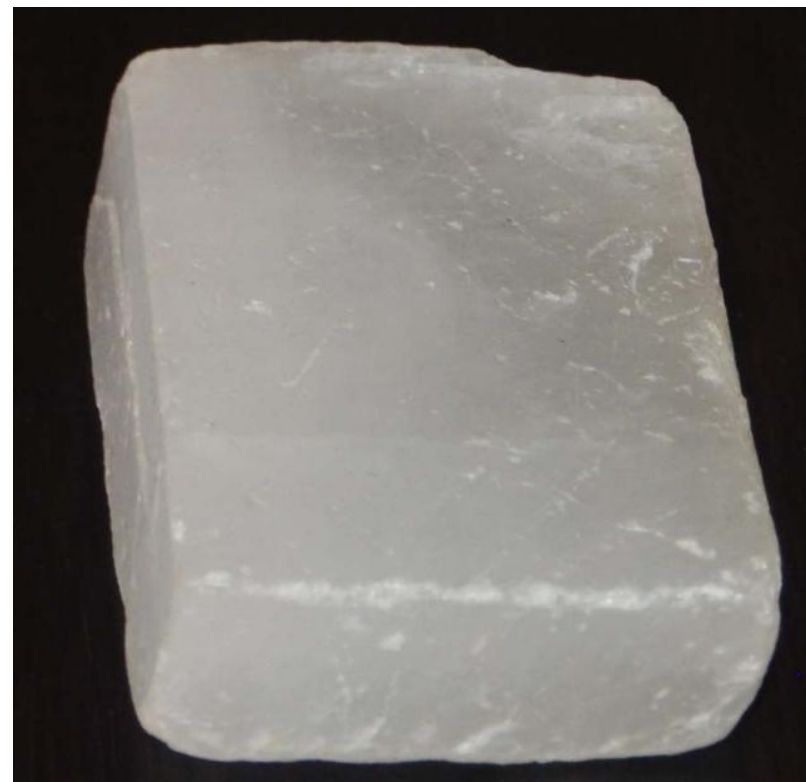

Figure 4: Rhombic shape crystal Calcite. 


\section{International Journal of Science and Research (IJSR) \\ ISSN (Online): 2319-7064}

Index Copernicus Value (2013): 6.14 | Impact Factor (2015): 6.391

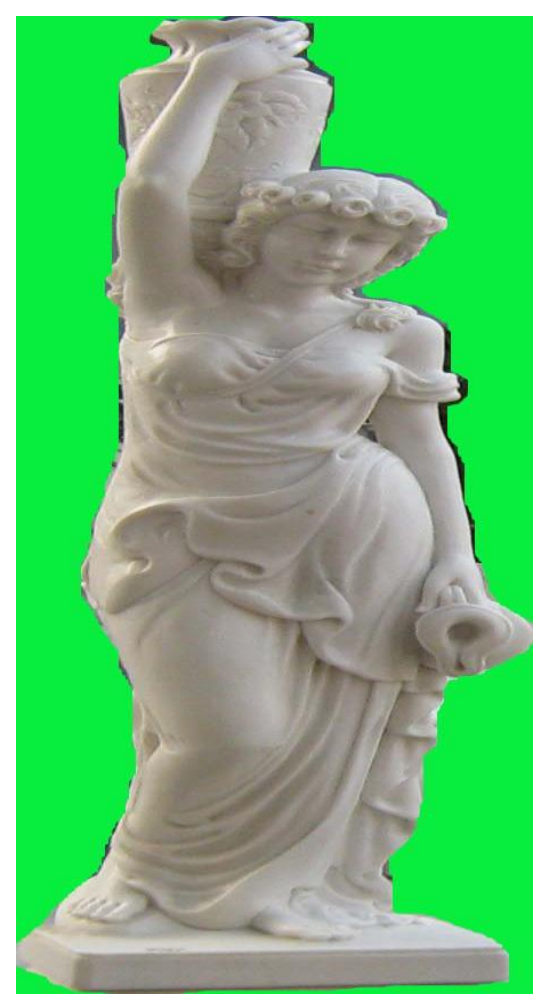

Figure 5: A finished statue made out of Marble

\section{References}

[1] D.K.Banerjee, Mineral Resources of India. The World Press Pvt. Ltd.,1992:

[2] K. K. Chatterjee, An introduction to Mineral Economics. Wiley Eastern Ltd., New Delhi, 1993.

[3] S.Deb,Industrial Minerals and Rocks and rocks of India, Allied publishers, 1980, 603.

[4] John W. Morse , Rolf S. Arvidson, and Andreas Lüttge,Calcium Carbonate Formation and Dissolution, Chem. Rev., 2007, 107 (2), 342-381.

[5] John D. Milliman, Production and accumulation of calcium carbonate in the ocean: Budget of a nonsteady state, 1993, 7 (4), 927-957

[6] Krishnaswamy, S.1988. India's MineralResources. 3rd Edn. Revised by R. K. Sinha. Oxford and I.B.H. Publishing

[7] L. Y. Luke Chang, Industrial Mineralogy: Materials, Processes and Use, Prentice Hall, 2002, 72.

[8] Navdeep K. Dhami, M. Sudhakara Reddyand Abhijit Mukherjee', Biomineralization of calcium carbonates and their engineered applications: a review, Front Microbial. 2013, 4: 314.

[9] U.Prasad, Economic Geology:Economic Mineral Deposits, CBS Publishers, 2012, 319.

[10]D.V.Reddy, Decorative and dimensional stones of India, CBS, 2008, 276.

[11]A. B.Roy\& S. R.Jakhar , Geology of Rajasthan (Northwest India) Precambrian to Recent. Scientific Publishers (India), 2012, 421.

[12] D.Perkins, Mineralogy, PHI Learning Pvt. Ltd., New Delhi, 2014,494 